\title{
Diderot leitor de Sêneca: o filósofo e o tirano
}

\author{
Maria das Graças de Souza
}

Universidade de São Paulo 

Diderot escreveu o Ensaio sobre os reinados de Claudio e de Nero, sobre os costumes de Roma e os escritos de Sêneca, para servir de introdução à leitura deste filósofo, em 1779. O ensaio foi planejado para ser o último volume de uma edição de obras completas de Sêneca, e atendeu a um pedido de Naigeon e d'Holbach, que, após a morte do primeiro editor, Lagrange, haviam se responsabilizado pela edição. Previsto para umas poucas páginas, o texto

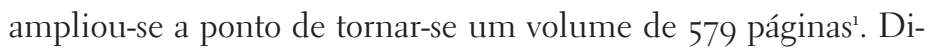
derot preparou-se longamente para escrevê-lo, e, na obra, cita praticamente todos os escritos do filósofo romano, além de dezenas de outros autores clássicos. Iniciadas as pesquisas, de acordo com os biógrafos, Diderot trabalhou nele obsessiva e obstinadamente.

Michel Delon, na notícia que precede as notas ao Ensaio, mostra que é por meio da vida e da obra de Sêneca que Diderot pretende "compreender o que ele mesmo viveu e fez" (Diderot, 2010, p. 1324). Não se trata apenas de fazer a sua própria apologia por intermédio da defesa do filósofo romano; segundo Delon, há no Ensaio mais do que isso: Diderot, ao escrever sobre Sêneca, quer inscrever a si mesmo e a Sêneca numa tradição de filosofia moral, ou numa interrogação de filosofia moral que se manifesta de século em século².

No artigo "La parole des autres" (A palavra dos outros), recentemente republicado, Jean Starobinski afirma que a apologia de Sêneca é a ocasião, para Diderot, de fazer a sua própria apologia, por pessoa interposta: ao esclarecer a vida do filósofo romano, em todo o seu percurso histórico, esta vida, interpretada, torna-se o meio de esclarecer a vida e a reputação de Diderot (Starobinski, 2012, p. 63). No Ensaio, continua Starobinski, Diderot com frequência não distingue a censura dirigida a Sêneca e as acusações que são dirigidas a ele mesmo, contra sua pessoa: "Uma mesma

1 Sobre as circunstâncias da composição da obra, ver Wilson, 1985, p. 576-578.

2 Cf. Diderot, 2010, p. 1325. 
palavra hostil, uma mesma maledicência sela a solidariedade entre Sêneca e Diderot; assim somos colocados em presença de uma causa comum" (Id., ibid., p. 64-65).

Mas o Ensaio não é apenas uma dupla apologia. Para Michel Delon, como vimos, Diderot, ao acompanhar a obra do pensador estoico, faz do Ensaio um livro de história e de reflexão política que se basta a si mesmo3. Para Starobinski, essa espécie de escritura marginal, essa transferência da palavra a um outro, que ele pratica no Ensaio e já havia praticado em vários outros textos, é um método "próprio para favorecer a intervenção crítica", que permite a Diderot abandonar-se à descontinuidade de suas ideias sucessivas, pelo quê ele se põe em cena sob diversas identidades (Starobinski, 2012).

Ora, até essa época, Diderot não havia mostrado interesse por Sêneca. Ao contrário, suas anteriores referências ao filósofo romano são hostis. Na tradução do Ensaio sobre o mérito e a virtude, de Shaftesbury, publicada em 1745, numa nota, ele havia duramente acusado Sêneca de ter se preocupado em amontoar riquezas, fazendo vistas grossas diante da crueldade de Nero, favorecendo a luxúria do imperador, seu pupilo. Ele diz mais: que Sêneca aceitou, num silêncio vergonhoso, a morte de cidadãos honrados que ele deveria e poderia ter defendido (Diderot, 2010, p. 787). Pouco mais de trinta anos depois, ele cita a si mesmo e se critica, afirmando que aquilo que mais o tocou na história do filósofo romano foi "a dificuldade e a dignidade de sua função" (Id., ibid.). O que teria mudado nesse longo intervalo? Por que Sêneca, antes condenado como uma espécie de traidor, agora é visto como "o mais sábio dos homens”, como diz o próprio Diderot no Ensaio ?

O filósofo responde que, entre uma afirmação e outra, ele "esteve às voltas consigo mesmo", e experimentou a "agonia do sábio”(Ibid.). O que significaria essa agonia ou angústia do sábio? 
Em primeiro lugar, há o caso da agonia real do próprio Sêneca: ele fora condenado à morte, por corte das veias; era velho, as veias rígidas, o sangue não corria; tomou veneno, o efeito não vinha; pediu para que o colocassem numa banheira de água quente, que deveria fazer esvair o sangue das veias... Foi uma longa agonia.

Em segundo lugar, de um ponto de vista filosófico mais geral, poder-se-ia pensar que a agonia do sábio consistiria na experiência do paradoxo que se manifesta na obra de Diderot sob várias formas: o paradoxo entre o homem do diafragma e o homem cerebral, no Paradoxo do comediante; o paradoxo daquele que, mesmo reconhecendo que sua vontade é determinada, age como se fosse livre (é o caso de Jacques); o paradoxo do filósofo que, embora afirme que o curso dos acontecimentos humanos é determinado pela força das coisas, compreende, todavia, a sua atividade de escritor como intervenção efetiva que pode transformar ou acelerar a cadeia dos acontecimentos.

Do ponto de vista de sua história pessoal, a agonia do sábio pode remeter às agruras pelas quais passou o filósofo na época de sua prisão em Vincennes e na interdição da Enciclopédia, e, sobretudo, à decepcionante estadia na corte russa como uma espécie de conselheiro da imperatriz Catarina (tal como Sêneca fora conselheiro de Nero), e que o teriam levado a refletir sobre as difíceis e complexas relações entre o filósofo, ou o homem de letras, e os poderes constituídos. Num caso como esse, deve-se ser inflexível do ponto de vista dos princípios? ou, em certas condições desfavoráveis, é preciso ceder um pouco, com vistas a um resultado futuro? Entre as convicções e as exigências das circunstâncias, como pode se manifestar a responsabilidade histórica do filósofo?

Roger Lewinter, em sua introdução ao Ensaio, mostra que, na época da tradução de Shaftesbury, Diderot se identificava com Sócrates. Quando, ao final de sua vida, escreve o Ensaio, ele identifica-se com Sêneca. O primeiro seria um ideal de perfeição abstrato, impossível na realidade, enquanto o segundo representa- 
ria uma imperfeição concreta, mas possível (Lewinter, 1972, p. 15). Acrescenta Lewinter que o filósofo, se quiser reformar o seu século por sua ação, deve levar em conta que esta ação não pode ser senão uma aproximação, uma mediação entre a verdade - absoluto intemporal - e a realidade - contingência temporal (Id., ibid.).

Se consideramos a trajetória de Diderot, vemos que desde muito cedo a questão da ação do filósofo está presente. No Passeio do cético, que é de 1747, ele havia escrito que se lhe fosse imposto silêncio sobre a religião e o governo, não teria mais nada a dizer (Diderot, 2010). No Prospecto da Enciclopédia (empreendimento que por si só é uma obra de militância), Diderot escreve que dedica a obra tanto "àqueles que têm a coragem de trabalhar para instruir os outros" quanto aos que "se instruem por si mesmos" (Encyclopédie, I); e, no verbete "Encyclopédie", também de sua autoria, afirma que a obra pretende "mudar a maneira geral de pensar" (Encyclopédie, V). Mas é a partir dos anos 1770 que sua reflexão assume um caráter mais eminentemente político.

Voltemos então à sua avaliação da figura de Sêneca. O que nos interessa aqui é o paralelo implícito estabelecido no Ensaio entre Sêneca conselheiro de Nero e Diderot conselheiro da Imperatriz Catarina. Desde sua chegada ao trono, Catarina tenta aproximar-se de Diderot, insistindo para que ele passe uma temporada em sua corte. Depois de adiar a viagem várias vezes, o filósofo enfim parte para São Petersburgo em 1773. A imperatriz, com isso, quer fazer figura de esclarecida; o filósofo, por sua vez, pensa poder convertê-la às Luzes. De fato, ele apresenta à Catarina um plano de reformas para o império, sem deixar de assinalar, contudo, as dificuldades daquele que tenta influenciar o destino dos povos por meio da influência exercida sobre os governantes. As notas preparadas para as conversas em São Petersburgo estão reunidas sob o título Mémoires pour Catherine II. "Nada é mais fácil, diz o filósofo, do que ordenar um império com a cabeça no travesseiro" (Diderot, 1963, p. 254). Não hesita em falar dos seus conselhos como "fantasias", e desculpa-se com Catarina pelo seu 
“cacarejar político". Mas, apesar disto, ele fica lá um bom tempo, conversa com a imperatriz sobre a modernização do império russo e apresenta propostas, sobre a organização política, o comércio, as manufaturas, a educação pública e até sobre assuntos militares. O resultado, evidentemente, não foi o esperado. Ao retornar à França, nas Observações sobre Nakaz, Diderot não esconderá sua desconfiança em relação aos propósitos de Catarina:

A imperatriz da Rússia, diz o filósofo, é certamente déspota. Sua intenção é manter o despotismo e transmiti-lo aos seus sucessores, ou de abdicar dele? Se ela mantém o despotismo para si e seus sucessores, que faça então seu código como bem entender. Não precisa do consentimento da nação. Mas, se quiser abdicar do despotismo, que essa abdicação seja formal; e, se for uma abdicação sincera, então que ela, juntamente com a nação, ocupe-se dos meios de impedir que o despotismo renasça, e que se leia no primeiro capítulo (do código), a infalível ruína daquele que tivesse no futuro a ambição de retornar à autoridade arbitrária da qual ela se desfaz. (Id., ibid., p. 437 ).

Na conclusão do texto, dirá claramente: "Vejo que ela abdicou do nome de déspota, mas a coisa foi conservada" (Id., ibid.). Em 1780, num dos numerosos fragmentos que escreveu para a História das duas Índias de Raynal, o filósofo não guarda nenhuma ilusão:

Ela abdicou verdadeiramente da autoridade despótica? Lendo com atenção suas instruções aos deputados do império, pode reconhecer alguma coisa que não seja o desejo de mudar apenas os nomes, de ser chamada de monarca em vez de autocrata, de chamar o povo de seus súditos ao invés de seus escravos? (Raynal, 1781, t. IV, p. 483).

Catarina leu as Observações sobre o Nakaz em 1785, quando Diderot já havia morrido. Escreveu então a Grimm, e disse que se tivesse feito o novo código ao gosto do filósofo, as coisas teriam fi- 
cado sem pé nem cabeça, e acrescentou que as observações de Diderot não mostravam nem prudência, nem conhecimento, nem clarividência. O empreendimento do filósofo fracassou. Mas, nas próprias Observações, ele de certo modo previra isso:

Ficaríamos consolados dos males passados e dos males presentes se o futuro mudasse este destino; mas essa é uma esperança que é impossível acalentar. E se perguntássemos ao filósofo para que servem os conselhos que ele insiste em oferecer às nações e aos que as governam, e ele respondesse com sinceridade, diria que satisfaz uma inclinação invencível para dizer a verdade, com o risco de excitar a indignação e até mesmo de beber da taça de Sócrates. (Diderot, 1963, p. 367).

De certo modo, a apologia de Sêneca no Ensaio é também uma defesa de si mesmo quanto à possibilidade de sucesso do filósofo conselheiro dos reis. O que fazia o filósofo de Córdoba no palácio de Nero? Era este o seu lugar? A experiência ainda não o havia ensinado que "o aluno que lhe haviam confiado não era digno de seus cuidados; que o imperador [...] não merecia o seu apreço, nem suas lições, nem seus serviços, nem seus conselhos"? (Id., ibid., p. 702.) Mas quem dirá ao sábio o momento de deixar seu posto, ou o momento em que convém morrer?

Vejo, diz Diderot, o homem honesto e sensível ficar desolado, afastar-se, olhar para trás, parar, voltar, e ter medo de se retirar cedo demais. [...] Mantém seu posto, vê que sua ruína se aproxima e a enfrenta. [...] É o que fez Sêneca. Colocai-vos no lugar do filósofo, do ministro, do preceptor, e tentai vos conduzir melhor do que ele. Id., ibid., p. 703).

Em sua defesa da permanência de Sêneca no que ele chama de "o covil da fera" ou antro da besta, Diderot julga que ele não podia abandonar Nero à sua própria perversidade sem cometer falta grave. Quanto mais um príncipe for ignorante, dissoluto, fraco ou feroz, mais é precioso um sábio a postos. 
Segundo Diderot, houve três etapas na vida pública de Sêneca: no início, ele tem esperanças; vendo que seu antigo discípulo se corrompe, ele se aflige; quando percebe que os vícios, a crueldade, a depravação e os furores de Nero se desenvolvem, ele quer se retirar (Id., ibid., p. 699). O paralelo Diderot-Catarina/ Sêneca-Nero manifesta que o filósofo, na experiência da agonia do sábio, é tomado por exigências contraditórias entre o compromisso militante e o risco de perder a integridade. Mas a retirada é ocasião de retomar a aspiração política de intervenção. O desencanto, lúcido, aparece na forma da crítica.

Desse modo, a produção de Diderot após a estadia em São Petersburgo mostra uma inflexão inesperada na sua reflexão política: se os déspotas não se esclarecem, só resta ao povo a rebelião. Vou tomar aqui apenas um caso em que esta inflexão se manifesta: uma passagem da Refutação de Helvétius, livro que ele finalizou após seu retorno de São Petersburgo. Trata-se do primeiro comentário de Diderot sobre uma referência de Helvétius, no prefácio de seu livro, sobre o estado da França. Ali, Helvétius havia escrito que a França da época era desprezada pela Europa e que não se poderia esperar que nenhuma crise salutar lhe restituiria a liberdade. Diderot discorda de Helvétius; não julga que a situação francesa seja tão ruim. Mas, a partir daí, ele toma, por assim dizer, a questão de fundo: em que condições uma nação que está definhando pode recuperar o seu vigor? Primeira alternativa: o surgimento de um salvador. Vejamos a passagem: “cedo ou tarde um braço vigoroso lhe restitui seu movimento" (Id., ibid., p. 456). Segunda alternativa: a rebelião. Cito: "sob qualquer governo que seja, a natureza pôs limites à infelicidade dos povos. Para além disto, é a morte, ou a fuga, ou a revolta" (Id., ibid.). Terceira alternativa: a violência, ou o banho de sangue: "Um dia me perguntaram como se podia restituir os costumes de um povo corrompido. Eu respondi: como Medeia devolveu a juventude ao seu pai: despedaçando-o e pondo-o para ferver". Essa imagem já havia aparecido numa carta a Wilkes de 1771, portanto antes 
da estadia na Rússia. Mas ela será outra vez retomada num dos fragmentos que Diderot escreveu para a História das duas Índias de Raynal. Na edição de 1781, ele diz:

Uma nação só se regenera num banho de sangue. É a imagem do velho Aesão, a quem Medeia devolveu a juventude despedaçando-o e pondo para ferver. Quando uma nação decai, não cabe a um homem reerguê-la. Parece que isto é obra de uma longa cadeia de revoluções. (Raynal, 1781 , t. IV, p, 146.)

O texto clássico que inspira a imagem está no livro VIII das Metamorfoses de Ovídio, em duas passagens: o rejuvenescimento de Aesão e o despedaçamento de Pélias, ambos pela arte de Medeia. Na verdade, Diderot opera uma modificação do texto de Ovídio. Na primeira narrativa de Ovídio, Aesão é rejuvenescido por Medeia mediante a abertura das veias do ancião e pela introdução nestas mesmas veias de uma poção mágica. Na segunda, Medeia sugere às filhas de Pélias, que também queriam ver seu pai rejuvenescido, um procedimento que vai acabar por despedaçá-lo. Na retomada feita por Diderot, ele associa elementos dos dois relatos, o despedaçamento e a regeneração. A imagem, ao ser retomada por Diderot, remete ao caráter violento dos processos de transformação social e política. Estas transformações se dão quando as condições de vida de um povo se tornam insuportáveis. Elas se dão, para usar as palavras do filósofo, na "extremidade do mal”. Elas se dão, por assim, dizer, pela força das coisas.

Desse modo, Diderot, por força do impacto do fracasso de sua experiência, por assim dizer, reformista, na corte de Catarina, é levado a operar em seu próprio pensamento político uma mudança notável: ele vai à Rússia movido pelo princípio das Luzes segundo o qual é possível influenciar o curso da história dos povos por meio do esclarecimento de seus governantes. Seu modelo é Sêneca, ministro de Nero. Mas Sêneca não conseguiu seu intento junto a Nero, nem Diderot o seu, junto a Catarina. Assim, ele 
se volta para os povos: são apenas eles que, se a situação for por demais adversa, deverão tomar nas mãos o seu próprio destino. $\mathrm{O}$ papel do filósofo continua a ser o de conselheiro, agora não mais dos tiranos, mas sim dos povos.

\section{Referências bibliográficas}

DIDEROT, D. Euvres politiques. Ed. Paul Vernière. Paris: Garnier, 1963 .

. Euvres philosophiques. Paris: Gallimard, 2010 (Col. Bibliothèque de la Pléiade).

DIDEROT, D .; D'ALEMBERT, J. Encyclopédie, ou dictionnaire raisonné des sciences, des arts et des métiers. 17 vols. Paris, $1751-1765$.

LEWINTER, R. "Introduction à Diderot". In: Essai sur les règnes de Claude et Néron. Paris: Bibliothèque 10/18, 1972.

RAYNAL, G.-T.. Histoire philosophique et politique des établissements et du commerce des Européens dans les deux Indes. Genève, 1781 .

STAROBINSKI, J. "La parole des autres". In: Diderot, un diable de ramage. Paris: Gallimard, 2012.

WILSON, Arthur M. Diderot, sa vie et son ouvre. Paris: Laffont/ Ramsay, 1985 . 
